\title{
Virulence of Puccinia triticina on Wheat in the United States in 1999
}

\author{
D. L. Long, Plant Pathologist, K. J. Leonard, Research Plant Pathologist, and M. E. Hughes, Biologist, Cereal \\ Disease Laboratory, USDA, Agricultural Research Service, Department of Plant Pathology, University of Minne- \\ sota, 1551 Lindig St., St. Paul 55108
}

\begin{abstract}
Long, D. L., Leonard, K. J., and Hughes, M. E. 2002. Virulence of Puccinia triticina on wheat in the United States in 1999. Plant Dis. 86:15-19.

Isolates of Puccinia triticina were obtained from wheat leaf collections made by cooperators throughout the United States and from surveys of wheat fields and nurseries in the Great Plains, Ohio Valley, and Gulf Coast states in 1999. Pathogenic races were determined from virulence/avirulence phenotypes on 14 host lines that are near-isogenic for leaf rust resistance. We found 58 races among 1,180 isolates in 1999. As in previous surveys, regional race distribution patterns showed that the central United States is a single epidemiological unit distinct from the eastern United States. The distinctive racial composition of collections from the Southeast, Northeast, and Ohio Valley indicates that populations of $P$. triticina in those areas are not closely connected, suggesting epidemics originate from localized overwintering sources.
\end{abstract}

Additional keywords: plant disease monitoring, Puccinia recondita, rust epidemiology, wheat leaf rust

Wheat leaf rust, caused by Puccinia triticina Eriks. (1) (= P. recondita Rob. ex Desmaz. f. sp. tritici), occurs annually throughout most wheat (Triticum aestivum) growing areas of the United States. In recent years, yield losses to leaf rust in wheat have ranged from trace levels $(<1 \%)$ in many states to $12 \%$ in California in 1996, $10 \%$ in Oklahoma in 1997, and 3.4\% in Kansas and $4.0 \%$ in Minnesota and North Dakota in 1999 (7). Losses to leaf rust in winter wheat in the United States were estimated at 4.8, $4.8,0.7,2.4,0.8,2.9,1.6$, and $2.2 \%$ in 1992 , 1993, 1994, 1995, 1996, 1997, 1998, and 1999, respectively (7). Losses in spring wheat were estimated at $0.5,0.3,0.0,0.1$, $0.0,1.1,0.8$, and $2.7 \%$ for the same years. Except in 1999, leaf rust losses have been lower in spring wheat than in winter wheat in the United States, mainly because of more effective resistance in spring wheat cultivars and because $P$. triticina rarely overwinters in the northern Great Plains where most spring wheat is grown.

Wheat leaf rust virulence surveys have been conducted by the Cereal Disease

Corresponding author: D. L. Long

E-mail: davidl@cdl.umn.edu

Accepted for publication 18 September 2001.

Publication no. D-2001-1109-10R

This article is in the public domain and not copyrightable. It may be freely reprinted with customary crediting of the source. The American Phytopathological Society, 2002.
Laboratory, formerly known as the Cereal Rust Laboratory, since 1978 to detect new pathogenic races and to monitor shifts of race frequencies in major wheat growing regions of the United States (12). Similar surveys have been done in Canada since 1931 (3) and in Mexico (20). In the United States (6) and Canada (2-5), leaf rust survey data have been used to characterize virulence and race dynamics and phenotypic diversity within and between wheat growing regions.

The objectives of this study were to characterize the virulence of $P$. triticina populations in the United States in 1999 to the North America wheat leaf rust differentials (8) and other selected lines of wheat, and to compare these results with those of previous surveys.

\section{MATERIALS AND METHODS}

Collections and race identification. Uredinial collections of leaf rust were made from wheat in annual surveys (over routes totaling approximately $20,000 \mathrm{~km}$ ) of the Great Plains, Ohio Valley, and Gulf Coast and by cooperators throughout the United States. In 1999, field surveys of wheat were made in southern and central Georgia (late March through May); eastern and southern Texas (early April); northern Texas and south central Oklahoma (late April); southeastern Gulf Coast (mid-April to early May); southeastern states (late April); Oklahoma and Kansas (mid-May); the Ohio River Valley (early June); north central Kansas, Nebraska, western Iowa,
South Dakota, and southern Minnesota (mid-June); and northern Plains states (early July and again in late July). Visual inspections for the presence of rust were made in commercial fields (4 to 50 ha in size) every $32 \mathrm{~km}$ or in the first field thereafter. Additional collections were made in wheat breeding nurseries, trap plots, and demonstration plots (collectively referred to as nurseries in data analysis) along the route. Nurseries typically contain a wide array of leaf rust resistance phenotypes including breeding lines with leaf rust resistance genes not yet in commercial cultivars. Trap plots usually contain older cultivars of wheat no longer prominent in commercial production. Leaf rust was also collected from goat grass, Triticum cylindricum Ces. (=Aegilops cylindrica Host), growing near wheat fields in Oklahoma. A collection consisted of one to several leaves bearing uredinia from a single plant or cultivar. The leaves were air-dried and stored at $4^{\circ} \mathrm{C}$ until spores were collected for inoculations. No collections from inoculated nurseries were included in the study.

Urediniospores from each collection were used to inoculate 7-day-old seedlings of the wheat cultivar Thatcher (CI 10003), treated at emergence with maleic hydrazide at approximately $0.01 \mathrm{~g}$ (dissolved in 30 $\mathrm{ml}$ of $\mathrm{H}_{2} \mathrm{O}$ ) per pot to enhance spore production (18). Plants were sprayed with a suspension of spores in lightweight mineral oil at a rate of approximately $0.5 \mathrm{ml}$ of spore suspension per pot of 10 to 20 seedlings. Inoculated plants were placed at $18^{\circ} \mathrm{C}$ in a dew chamber overnight. The plants were then transferred to a greenhouse where temperatures varied between 18 and $28^{\circ} \mathrm{C}$ daily under natural light. After 12 to 15 days, three seedlings were saved per collection, each with the primary leaf trimmed to bear a single uredinium. Six to 9 days later, a cyclone spore collector was used to collect urediniospores separately from one or two such uredinia per collection. If the single uredinia were small and few spores were collected, the isolates were increased through one uredinial generation on Thatcher before inoculating differential lines. Otherwise, spores from the single uredinia were directly inoculated onto 7- to 8-day-old plants of the differential host series (five to seven plants 
per line) of near isogenic lines of Thatcher with single resistance genes $L r l, 2 a, 2 c$, $3 a, 3 k a, 9,10,11,16,17,18,24,26$, and 30. Lines included in this standard set of differentials were chosen by the North American Leaf Rust Workers Committee (8) because they account for a large part of the detectable diversity in virulence of $P$. triticina in North America and because they react with distinct low or high infection types. Sets of differential lines grown during June through September received no supplemental light. From October through May, natural daylight was supplemented with high-pressure sodium lamps from 0200 to 1400 (400 to $450 \mu \mathrm{E} \cdot \mathrm{m}^{-2} \cdot \mathrm{s}^{-1}$ at bench level). After 10 to 14 days, infection types were recorded as either high (IT 3-4) or low (IT 0-2+) as in previous surveys (9-15). Race designations were assigned as described by Long and Kolmer (8).

Race and virulence frequencies were determined for collections from seven of eight agroecological geographic areas (Fig. 1): area 1, mainly southern-adapted soft

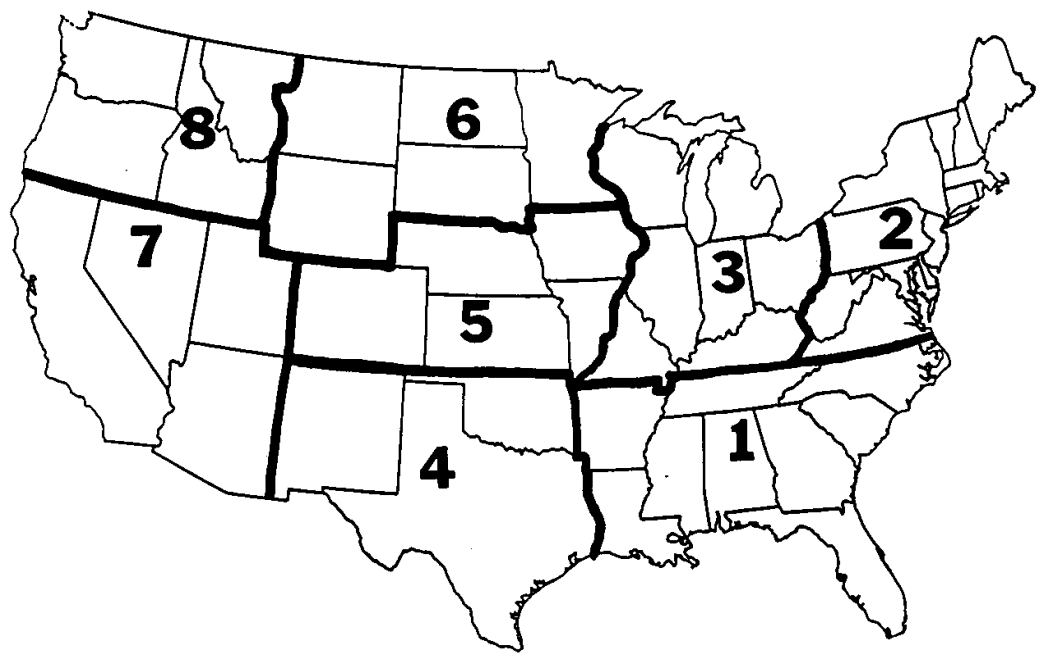

Fig. 1. Agroecological areas for Puccinia triticina in the United States. Winter wheat is grown in areas 1 to 5 and 8; spring wheat is grown in areas 6 and 7 . Hard red wheat cultivars are grown in areas 4 to 6 ; soft red or white cultivars, in areas 1 to 3 ; and mainly soft white cultivars, in area 8.

Table 1. North American wheat leaf rust nomenclature $(\mathrm{Pt})$ code and corresponding virulence formula for races identified in 1999

\begin{tabular}{|c|c|c|c|}
\hline Pt code ${ }^{a}$ & Virulence formula ${ }^{b}$ & Pt code & Virulence formula \\
\hline FBM-10,18 & $2 \mathrm{c}, 3 \mathrm{a}, 3 \mathrm{ka}, 10,18,30$ & TBD-10 & $1,2 \mathrm{a}, 2 \mathrm{c}, 3 \mathrm{a}, 10,17$ \\
\hline FBR-10,18 & $2 \mathrm{c}, 3 \mathrm{a}, 3 \mathrm{ka}, 10,11,18,30$ & TBM-10 & $1,2 \mathrm{a}, 2 \mathrm{c}, 3 \mathrm{a}, 3 \mathrm{ka}, 10,30$ \\
\hline FCM-10,18 & 2c, 3a, 3ka, 10, 18, 26, 30 & TBR-10 & $1,2 \mathrm{a}, 2 \mathrm{c}, 3 \mathrm{a}, 3 \mathrm{ka}, 10,11,30$ \\
\hline KFB-10 & $2 \mathrm{a}, 2 \mathrm{c}, 3 \mathrm{a}, 10,24,26$ & TBR-10,18 & $1,2 \mathrm{a}, 2 \mathrm{c}, 3 \mathrm{a}, 3 \mathrm{ka}, 10,11,18,30$ \\
\hline LCG-18 & $1,11,18,26$ & TCB-10 & $1,2 \mathrm{a}, 2 \mathrm{c}, 3 \mathrm{a}, 10,26$ \\
\hline MBB-10 & $1,3 \mathrm{a}, 10$ & TCB-10,18 & $1,2 \mathrm{a}, 2 \mathrm{c}, 3 \mathrm{a}, 10,18,26$ \\
\hline MBD-10 & $1,3 \mathrm{a}, 10,17$ & TCD-10 & $1,2 \mathrm{a}, 2 \mathrm{c}, 3 \mathrm{a}, 10,17,26$ \\
\hline MBG & $1,3 \mathrm{a}, 11$ & TCM-10 & $1,2 \mathrm{a}, 2 \mathrm{c}, 3 \mathrm{a}, 3 \mathrm{ka}, 10,26,30$ \\
\hline MBG-10 & $1,3 \mathrm{a}, 10,11$ & TCM-10,18 & $1,2 \mathrm{a}, 2 \mathrm{c}, 3 \mathrm{a}, 3 \mathrm{ka}, 10,18,26,30$ \\
\hline MBG-10,18 & $1,3 \mathrm{a}, 10,11,18$ & TCR-10 & $1,2 \mathrm{a}, 2 \mathrm{c}, 3 \mathrm{a}, 3 \mathrm{ka}, 10,11,26,30$ \\
\hline MBK-10 & $1,3 \mathrm{a}, 10,11,17,30$ & TDB-10 & $1,2 \mathrm{a}, 2 \mathrm{c}, 3 \mathrm{a}, 10,24$ \\
\hline MBR-10 & $1,3 \mathrm{a}, 3 \mathrm{ka}, 10,11,30$ & TDG-10 & $1,2 \mathrm{a}, 2 \mathrm{c}, 3 \mathrm{a}, 10,11,24$ \\
\hline MBR-10,18 & $1,3 \mathrm{a}, 3 \mathrm{ka}, 10,11,18,30$ & TDR & $1,2 \mathrm{a}, 2 \mathrm{c}, 3 \mathrm{a}, 3 \mathrm{ka}, 11,24,30$ \\
\hline MCB-10 & $1,3 a, 10,26$ & TDR-10 & $1,2 \mathrm{a}, 2 \mathrm{c}, 3 \mathrm{a}, 3 \mathrm{ka}, 10,11,24,30$ \\
\hline MCD-10 & $1,3 \mathrm{a}, 10,17,26$ & TDR-10,18 & $1,2 \mathrm{a}, 2 \mathrm{c}, 3 \mathrm{a}, 3 \mathrm{ka}, 10,11,18,2430$ \\
\hline MCG-10 & $1,3 \mathrm{a}, 10,11,26$ & TFB-10 & $1,2 \mathrm{a}, 2 \mathrm{c}, 3 \mathrm{a}, 10,24,26$ \\
\hline MCR-10 & $1,3 \mathrm{a}, 3 \mathrm{ka}, 10,11,26,30$ & TFG-10 & $1,2 \mathrm{a}, 2 \mathrm{c}, 3 \mathrm{a}, 10,11,24,26$ \\
\hline MCR-10,18 & $1,3 \mathrm{a}, 3 \mathrm{ka}, 10,11,18,26,30$ & TFM-10 & $1,2 \mathrm{a}, 2 \mathrm{c}, 3 \mathrm{a}, 3 \mathrm{ka}, 10,24,26,30$ \\
\hline MCT-10 & $1,3 \mathrm{a}, 3 \mathrm{ka}, 10,11,17,26,30$ & TFR-10 & $1,2 \mathrm{a}, 2 \mathrm{c}, 3 \mathrm{a}, 3 \mathrm{ka}, 10,11,24,26,30$ \\
\hline MDB-10 & $1,3 \mathrm{a}, 10,24$ & TGB-10 & $1,2 \mathrm{a}, 2 \mathrm{c}, 3 \mathrm{a}, 10,16$ \\
\hline MDR-10 & $1,3 \mathrm{a}, 3 \mathrm{ka}, 10,11,24,30$ & THB-10 & $1,2 \mathrm{a}, 2 \mathrm{c}, 3 \mathrm{a}, 10,16,26$ \\
\hline MFB-10 & $1,3 a, 10,24,26$ & THD-10 & $1,2 \mathrm{a}, 2 \mathrm{c}, 3 \mathrm{a}, 10,16,17,26$ \\
\hline MGB-10 & $1,3 \mathrm{a}, 10,16$ & THM-10 & $1,2 \mathrm{a}, 2 \mathrm{c}, 3 \mathrm{a}, 3 \mathrm{ka}, 10,16,26,30$ \\
\hline MGD-10 & $1,3 \mathrm{a}, 10,16,17$ & TJB-10 & $1,2 \mathrm{a}, 2 \mathrm{c}, 3 \mathrm{a}, 10,16,24$ \\
\hline PBR-10,18 & $1,2 \mathrm{c}, 3 \mathrm{a}, 3 \mathrm{ka}, 10,11,18,30$ & TKB-10 & $1,2 \mathrm{a}, 2 \mathrm{c}, 3 \mathrm{a}, 10,16,24,26$ \\
\hline PNM-10,18 & $1,2 \mathrm{c}, 3 \mathrm{a}, 3 \mathrm{ka}, 9,10,18,24,30$ & TLG-18 & $1,2 \mathrm{a}, 2 \mathrm{c}, 3 \mathrm{a}, 9,11,18$ \\
\hline SBD & $1,2 \mathrm{a}, 2 \mathrm{c}, 17$ & TLG-10,18 & $1,2 \mathrm{a}, 2 \mathrm{c}, 3 \mathrm{a}, 9,10,11,18$ \\
\hline SBJ-10 & $1,2 \mathrm{a}, 2 \mathrm{c}, 10,11,17$ & TLR-10 & $1,2 \mathrm{a}, 2 \mathrm{c}, 3 \mathrm{a}, 3 \mathrm{ka}, 9,10,11,30$ \\
\hline TBB-10 & $1,2 \mathrm{a}, 2 \mathrm{c}, 3 \mathrm{a}, 10$ & TNR-10 & $1,2 \mathrm{a}, 2 \mathrm{c}, 3 \mathrm{a}, 3 \mathrm{ka}, 9,10,11,24,30$ \\
\hline
\end{tabular}

a Race code plus $L r 10$ and $L r 18$ near-isogenic supplements.

${ }^{\mathrm{b}}$ Resistances evaluated: $\operatorname{Lrl}, 2 a, 2 c, 3 a, 3 k a, 9,10,11,16,17,18,24,26$, and 30.

red winter wheats; areas 2 and 3, mostly northern-adapted soft red and white winter wheats that appear to be epidemiologically separated by geographic features; area 4 , mixed wheat types but primarily hard red winter; area 5, hard red winter wheat; area 6 , mixed wheat types but primarily hard red spring and durum; area 7 , spring wheat planted in late fall; and area 8, mixed wheat types but primarily soft white winter. There were no collections from area 8 in 1999.

\section{RESULTS AND DISCUSSION}

Races identified. Leaf rust infection was widespread in the southern and central Great Plains and much heavier than normal in the northern Great Plains in 1999. A total of 1,180 single uredinial isolates were characterized, and 58 races were identified in 1999 (Table 1) based on high/low infection types on the 12 differential host lines plus a Thatcher line with $\mathrm{LrIO}$ and one with $\operatorname{Lr} 18$ (8). Races found in areas 1 to 7 are arranged by the North American wheat leaf rust code (8) in Table 2. Results are presented as percentages of isolates within areas separated into collections made from nurseries and fields.

The M-- race group (virulent on $\mathrm{Lrl}$ and $3 a$ ) comprised $59 \%$ of the total number of leaf rust isolates identified in 1999. The most frequently identified race group in 1999 was M_D (virulent on $L r l, 3 a$, and 17), which comprised $24 \%$ of the nationwide sample. The most common race MBD-10 was found in areas 2, 3, 4, 5, 6, and 7 of the United States in 1999 (Table 2). Race MBD-10 comprised 13, 9, 4, and $1 \%$ in $1999,1998,1997$, and 1996, respectively (9). MBD-10 was not found in 1995 (10). MCD-10, the fourth most widely identified race in 1999 at $9 \%$ of the population, was found at $12,8,4$, and $0.3 \%$ in 1998, 1997, 1996 (9), and 1995 (10), respectively. MCR-10,18 (virulent to $L r l$, $3 a, 3 k a, 10,11,18,26$, and 30) was the third most widely identified race in 1999 , and comprised $10 \%$ of the population. This race was identified from rust collections made only in areas 1, 2, and 3. MCR-10,18 was not identified in 1998 or 1996 but comprised $4 \%$ of the identified isolates in 1997 (9). MDR-10 (virulent on Lrl, 3a, $3 k a, 10,11,24$, and 30 ) comprised $6 \%$ of the nationwide sample in 1999, although it was the most frequently found race in 1997 and 1998, comprising $23 \%$ of the nationwide population in both years (9). MDR-10 comprised 3\% of the population in 1996 and $0.3 \%$ in $1995(9,10)$. Race MDR-10 was found in all areas of the United States except in area 7. MBR-10 and MBR-10,18 (virulent to $L r l, 3 a, 3 k a, 11$, and 30 ) together comprised $13,18,23$, and $44 \%$ of the nationwide sample in 1999, 1998, 1997, and 1996, respectively (9). In 1999, these two races were found in all areas of the United States except in area 7. The other $13 \mathrm{M}$-- races together comprised $9 \%$ 
of the nationwide sample in 1999 (Table 2).

Thirty T-- races (virulent on $L r l, 2 a, 2 c$, and $3 a$ ) formed the second largest group of races and comprised $38 \%$ of the isolates in 1999. The races were found at 23,21 , and $15 \%$ of the nationwide sample in 1998 ,
1997, and 1996, respectively (9). Race THB-10 was the second most widely identified race in 1999 and comprised 12\% of the isolates. Most THB-10 isolates were found in area 6. In 1998 and 1997, THB-10 comprised only 1 and $0.2 \%$ of the isolates nationally. Race group TC- (virulent to
Lrl, 2a, 2c, 3a, 10, and 26) comprised $7 \%$ of the isolates identified in 1999. Race group TD- (virulent to $L r l, 2 a, 2 c, 3 a, 10$, and 24) comprised 5\% in 1999 (Table 2). The TLG-18 race was common in area 2 and comprised $4 \%$ of the isolates nationally in 1999 (Table 2). TLG-18 comprised

Table 2. Frequency and distribution of races of Puccinia triticina collected from fields (F) and nurseries (N) in agroecological areas 1 (Southeast), 2 (Northeast), 3 (Ohio Valley), 4 (Southern Plains), 5 (Central Plains), 6 (Northern Plains), and 7 (Southwest) of the United States in 1999

\begin{tabular}{|c|c|c|c|c|c|c|c|c|c|c|c|c|c|c|}
\hline \multirow[b]{3}{*}{ Pt $\operatorname{code}^{\mathrm{a}}$} & \multicolumn{14}{|c|}{ Isolates from indicated source (\%) } \\
\hline & \multicolumn{2}{|c|}{ Area $1^{b}$} & \multicolumn{2}{|c|}{ Area 2} & \multicolumn{2}{|c|}{ Area 3} & \multicolumn{2}{|c|}{ Area 4} & \multicolumn{2}{|c|}{ Area 5} & \multicolumn{2}{|c|}{ Area 6} & \multicolumn{2}{|c|}{ Area 7} \\
\hline & $\mathbf{F}$ & $\mathbf{N}$ & $\mathbf{F}$ & $\mathbf{N}$ & $\mathbf{F}$ & $\mathbf{N}$ & $\mathbf{F}$ & $\mathbf{N}$ & $\mathbf{F}$ & $\mathbf{N}$ & $\mathbf{F}$ & $\mathbf{N}$ & $\mathbf{F}$ & $\mathbf{N}$ \\
\hline FBM-10,18 & 0 & 1 & 0 & 0 & 0 & 1 & 0 & 0 & 0 & 0 & 0 & 0 & 0 & 0 \\
\hline FBR-10,18 & 0 & 3 & 0 & 0 & 0 & 0 & 0 & 0 & 0 & 0 & 0 & 0 & 0 & 0 \\
\hline FCM-10,18 & 0 & 1 & 0 & 0 & 0 & 0 & 0 & 0 & 0 & 0 & 0 & 0 & 0 & 0 \\
\hline KFB-10 & 0 & 0 & 0 & 0 & 0 & 0 & 0 & 0 & 0 & 0 & 0 & 1 & 0 & 0 \\
\hline LCG-18 & 0 & 1 & 0 & 0 & 0 & 0 & 0 & 0 & 0 & 0 & 0 & 0 & & 0 \\
\hline MBB-10 & 0 & 0 & 0 & 0 & 0 & 0 & 0 & 0 & 0 & 0 & 1 & 0 & 0 & 0 \\
\hline MBD-10 & 0 & 0 & 0 & 14 & 5 & 4 & 8 & 24 & 33 & 18 & 20 & 19 & 0 & 20 \\
\hline MBG & 0 & 0 & 0 & 0 & 0 & 4 & 0 & 0 & 0 & 0 & 0 & 0 & 0 & 0 \\
\hline MBG-10 & 13 & 3 & 0 & 14 & 0 & 4 & 0 & 3 & 0 & 0 & 0 & 0 & 100 & 80 \\
\hline MBG-10,18 & 0 & 1 & 0 & 0 & 0 & 0 & 2 & 1 & 0 & 0 & 0 & 0 & 0 & 0 \\
\hline MBK-10 & 0 & 0 & 0 & 0 & 0 & 0 & 6 & 6 & 0 & 0 & 0 & 0 & 0 & 0 \\
\hline MBR-10 & 19 & 10 & 0 & 0 & 9 & 0 & 0 & 4 & 0 & 18 & 2 & 3 & 0 & 0 \\
\hline MBR-10,18 & 13 & 18 & 75 & 21 & 9 & 16 & 0 & 1 & 0 & 0 & 1 & 1 & 0 & 0 \\
\hline MCB-10 & 13 & 0 & 0 & 0 & 0 & 2 & 0 & 0 & 0 & 0 & 0 & 1 & 0 & 0 \\
\hline MCD-10 & 0 & 0 & 0 & 0 & 7 & 12 & 38 & 24 & 0 & 28 & 6 & 8 & 0 & 0 \\
\hline MCG-10 & 0 & 1 & 0 & 0 & 0 & 0 & 0 & 0 & 0 & 0 & 2 & 1 & 0 & 0 \\
\hline MCR-10 & 0 & 2 & 0 & 0 & 5 & 0 & 0 & 1 & 0 & 0 & 0 & 0 & 0 & 0 \\
\hline MCR-10,18 & 13 & 34 & 0 & 21 & 2 & 16 & 0 & 0 & 0 & 0 & 0 & 0 & 0 & 0 \\
\hline MCT-10 & 0 & 0 & 0 & 0 & 0 & 0 & 2 & 0 & 0 & 0 & 0 & 0 & 0 & 0 \\
\hline MDB-10 & 0 & 1 & 0 & 0 & 0 & 0 & 0 & 0 & 33 & 0 & 2 & $* \mathrm{c}$ & 0 & 0 \\
\hline MDR-10 & 0 & 4 & 0 & 0 & 0 & 2 & 8 & 14 & 0 & 10 & 6 & 6 & 0 & 0 \\
\hline MFB-10 & 0 & 0 & 0 & 0 & 0 & 4 & 0 & 1 & 0 & 0 & 0 & 1 & 0 & 0 \\
\hline MGB-10 & 0 & 0 & 0 & 0 & 0 & 0 & 0 & 0 & 0 & 0 & 2 & 1 & 0 & 0 \\
\hline MGD-10 & 0 & 0 & 0 & 0 & 0 & 0 & 0 & 1 & 0 & 0 & 7 & 2 & 0 & 0 \\
\hline PBR-10,18 & 0 & 0 & 0 & 0 & 7 & 0 & 0 & 0 & 0 & 0 & 0 & 0 & 0 & 0 \\
\hline PNM-10,18 & 0 & * & 0 & 0 & 0 & 0 & 0 & 0 & 0 & 0 & 0 & 0 & 0 & 0 \\
\hline SBD & 0 & 0 & 0 & 0 & 0 & 0 & 21 & 0 & 0 & 0 & 0 & 0 & 0 & 0 \\
\hline SBJ-10 & 0 & 0 & 0 & 0 & 0 & 0 & 4 & 0 & 0 & 0 & 0 & 0 & 0 & 0 \\
\hline TBB-10 & 0 & 0 & 0 & 0 & 0 & 2 & 0 & 1 & 0 & 0 & 2 & 1 & 0 & 0 \\
\hline TBD-10 & 0 & 0 & 0 & 0 & 0 & 0 & 0 & 1 & 0 & 0 & 0 & * & 0 & 0 \\
\hline TBM-10 & 0 & 0 & 0 & 0 & 4 & 0 & 0 & 0 & 0 & 0 & 0 & 0 & 0 & 0 \\
\hline TBR-10 & 13 & * & 0 & 0 & 0 & 0 & 0 & 0 & 0 & 0 & 2 & 1 & 0 & 0 \\
\hline TBR-10,18 & 0 & 0 & 0 & 0 & 7 & 2 & 0 & 0 & 0 & 0 & 0 & 0 & 0 & 0 \\
\hline TCB-10 & 0 & 1 & 0 & 0 & 4 & 4 & 2 & 1 & 0 & 0 & 0 & 2 & 0 & 0 \\
\hline TCB-10,18 & 0 & 1 & 0 & 0 & 0 & 0 & 0 & 0 & 0 & 0 & 0 & 0 & 0 & 0 \\
\hline TCD-10 & 0 & 0 & 0 & 0 & 0 & 0 & 0 & 0 & 0 & 5 & 0 & 0 & 0 & 0 \\
\hline TCM-10 & 0 & 0 & 0 & 0 & 0 & 2 & 0 & 0 & 0 & 0 & 0 & 3 & 0 & 0 \\
\hline TCM-10,18 & 0 & 1 & 0 & 0 & 4 & 0 & 0 & 0 & 0 & 0 & 0 & 1 & 0 & 0 \\
\hline TCR-10 & 0 & 2 & 0 & 0 & 11 & 20 & 0 & 3 & 0 & 8 & 2 & 4 & 0 & 0 \\
\hline TDB-10 & 0 & $*$ & 0 & 0 & 0 & 0 & 0 & 0 & 0 & 13 & 3 & 2 & 0 & 0 \\
\hline TDG-10 & 0 & 0 & 0 & 0 & 0 & 0 & 2 & 1 & 0 & 0 & 0 & 0 & 0 & 0 \\
\hline TDR & 0 & 0 & 0 & 0 & 0 & 0 & 0 & 0 & 0 & 0 & 0 & 1 & 0 & 0 \\
\hline TDR-10 & 0 & $*$ & 0 & 0 & 2 & 4 & 0 & 1 & 0 & 3 & 0 & 7 & 0 & 0 \\
\hline TDR-10,18 & 0 & 1 & 0 & 0 & 4 & 0 & 0 & 0 & 0 & 0 & 0 & 0 & 0 & 0 \\
\hline TFB-10 & 0 & 1 & 0 & 0 & 0 & 0 & 4 & 2 & 33 & 0 & 0 & $*$ & 0 & 0 \\
\hline TFG-10 & 0 & 0 & 0 & 0 & 0 & 0 & 0 & 1 & 0 & 0 & 0 & 0 & 0 & 0 \\
\hline TFM-10 & 0 & 0 & 0 & 0 & 0 & 0 & 0 & 0 & 0 & 0 & 1 & 1 & 0 & 0 \\
\hline TFR-10 & 0 & 0 & 0 & 0 & 0 & 2 & 4 & 6 & 0 & 0 & 2 & 3 & 0 & 0 \\
\hline TGB-10 & 0 & 0 & 0 & 0 & 0 & 0 & 0 & 1 & 0 & 0 & 0 & 2 & 0 & 0 \\
\hline THB-10 & 19 & 0 & 0 & 0 & 5 & 0 & 0 & 0 & 0 & 0 & 42 & 23 & 0 & 0 \\
\hline THD-10 & 0 & 0 & 0 & 0 & 0 & 0 & 0 & 0 & 0 & 0 & 0 & 1 & 0 & 0 \\
\hline THM-10 & 0 & 0 & 0 & 0 & 16 & 0 & 0 & 0 & 0 & 0 & 0 & 0 & 0 & 0 \\
\hline TJB-10 & 0 & 0 & 0 & 0 & 0 & 0 & 0 & 0 & 0 & 0 & 0 & 1 & 0 & 0 \\
\hline TKB-10 & 0 & 0 & 0 & 0 & 0 & 0 & 0 & 0 & 0 & 0 & 0 & 1 & 0 & 0 \\
\hline TLG-18 & 0 & 14 & 25 & 29 & 0 & 0 & 0 & 0 & 0 & 0 & 0 & 1 & 0 & 0 \\
\hline TLG-10,18 & 0 & 0 & 0 & 0 & 0 & 0 & 0 & 1 & 0 & 0 & 0 & 0 & 0 & 0 \\
\hline TLR-10 & 0 & 0 & 0 & 0 & 0 & 0 & 0 & 0 & 0 & 0 & 0 & 1 & 0 & 0 \\
\hline TNR-10 & 0 & 1 & 0 & 0 & 0 & 0 & 0 & 0 & 0 & 0 & 0 & 2 & 0 & 0 \\
\hline No. isolates & 16 & 296 & 4 & 14 & 56 & 50 & 52 & 147 & 3 & 40 & 127 & 363 & 2 & 10 \\
\hline
\end{tabular}

${ }^{a}$ Races based on 12 North American leaf rust differential lines (11) plus supplemental lines with $\operatorname{Lr} 10$ and $\operatorname{Lr} 18$.

${ }^{\mathrm{b}}$ Agroecological areas are shown in Figure 1.

c $*=$ less than $1 \%$. 
6,4 , and $3 \%$ of the nationwide sample in 1998, 1997, and 1996, respectively (9), and 1,6 , and $9 \%$ in 1995, 1994, and 1993, respectively (10). In the years from 1993 through to 1999 , this race almost exclusively was identified from rusted soft red winter wheat collections (i.e., CK 9835) from areas 1 and 2 (Table 2) $(9,10)$. The T- races (virulent to $L r l, 2 a, 2 c$, and $3 a$ ) are a very diverse group, with 15 of the $30 \mathrm{~T}$-races identified in 1999 comprising less than $4 \%$ of the total nationwide sample (Table 2).

The M-- races were common in all seven areas sampled in 1999. All of the isolates from area 7 were M-- races, as were $74 \%$ of those from areas $1,2,4$, and 5 , and $45 \%$ from areas 3 and 6 . The T-races were more common in area $6(56 \%)$ and area $3(46 \%)$ than in the other areas. Although overall M-- races were less common in area 6 (northern plains) than in areas 4 (southern plains) and area 5 (central plains), the most common race, MBD10 , occurred at higher frequencies in areas 4,5 , and 6 than in other areas. This is consistent with earlier conclusions that leaf rust spreads freely throughout the Great Plains, but movement between other areas is less common (6).

In the 1999 nationwide survey, the combined race groups F-- (virulent on $L r 2 c$, $3 a$ ), L-- (virulent on $L r l$ ), and P-- (virulent on $L r 1,2 c, 3 a$ ) represented $2 \%$ of all isolates identified (Table 2) and were found scattered throughout the eastern soft red winter wheat region.

The 11 isolates of race SBD and two isolates of SBJ-10, comprising $1 \%$ of the isolates nationwide, all came from central and southwestern Oklahoma and were from collections of rusted plants of $T$. cylindricum either on roadsides or in wheat fields.

Virulence frequencies. Frequencies of virulence on each of the 14 differential lines differed among collections from the eight agroecological areas (Table 3). Due to variation in greenhouse environment, temperature sensitive genes $L r 3 k a, 11,17$, and 18 may have been misclassified occasionally. Avirulent isolates may give intermediate to susceptible reactions on lines with $L r 3 k a, L r l l$, or $L r l 8$ at high $\left(>25^{\circ} \mathrm{C}\right)$ temperatures, whereas resistant reactions on the lines with $\operatorname{Lr} 17$ may be difficult to distinguish from susceptibility at abnormally low temperatures for some leaf rust isolates. These temperature effects were minimized by suspending race identification work in the greenhouse during July and August.

Incidence of virulence on lines with Lr26 represented $47 \%$ of the total U.S. isolates in 1999 (Table 3), which had increased from 34\% in 1998 (9). In 1986, less than $1 \%$ of isolates were virulent to Lr26 (14). Virulence to $L r 24$ has ranged from $2 \%$ in 1986 (14) to $41 \%$ in 1997 (9) and $17 \%$ in 1999 (Table 3). Virulences to $L r 24$ and $L r 26$ were most common in areas 4, 5 , and 6 (Table 3). Cultivars with $L r 24$ are widely grown in the southern Great Plains (16).

Virulence to $\mathrm{Lrll}$ was found in $51 \%$ of the race population throughout the United States and was identified in 28 races in 1999. From 1996 to 1998, the number of races virulent on $\mathrm{Lr} 11$ increased from 16 to 34 (9). This reflects a selective advantage of this virulence due to an increase in the acreage of cultivars with LrII (19). The number of races found with virulence to Lrll also suggests an accumulation of independent mutations to $L r l 1$ virulence in a variety of genetic lineages in the $P$. triticina populations. Virulence to $\mathrm{Lr} 11$ was most frequent in M-- and T-- races, the two most common race groups.

Virulence to $\operatorname{Lr} 17$ was identified in $27 \%$ of the nationwide sample of $P$. triticina in 1999. $\mathrm{Lr} 17$ was found in 9, 16, and $21 \%$ of the nationwide sample in 1996, 1997, and 1998, respectively. In 1994 and 1995 (10),
Lr17 virulence was identified in only $2 \%$ of the nationwide population. This increase in virulence from $2 \%$ in 1995 to $27 \%$ in 1999 directly correlates with a significant increase in the acreage of Jagger, a hard red winter cultivar with $\operatorname{Lrl7}$ (17) resistance.

Virulence to Lrl6 was identified in $17 \%$ of the nationwide sample in 1999 (Table 3 ). The last time there was such high virulence to Lrl6 was in 1986, when $17 \%$ of the race population was virulent to Lrl6 (14). Less than $1 \%$ of the U.S. population was virulent to Lrl6 in 1997 (9). In 1999, seven phenotypes (MGB, MGD, TGB, THB, THM, TJB, and TKB) were identified with virulence to Lr16 (Table 1). In Canada, virulence to $\operatorname{Lr} 16$ occurred in $6 \%$ of the isolates in 1987 (2) and $17.2 \%$ in 1998 (5), but it was not found from 1989 to 1994 (5). The increase in virulence to Lr16, particularly in area 6, may account for the leaf rust losses that were much higher than normal on spring wheat in the northern plains states in 1999 (7). Many of the currently grown spring wheat cultivars have Lrl6 as part of their resistance (17). Interestingly, none of the leaf rust isolates from the southern Great Plains and only $1 \%$ of those from the central Great Plains in 1999 were virulent on Lrl6 (Table 3).

Virulence to $\operatorname{Lr} 9$ was identified in $5 \%$ in 1999 and 4, 5, and 3\% of the nationwide sample of $P$. triticina in 1996, 1997, and 1998, respectively (9). In 1999, Lr9 virulence was found only in the PN-, TL-, and $\mathrm{TN}$ - races and mainly in the eastern soft red winter wheat region (areas 1, 2, and 3). $\mathrm{Lr} 9$ is found almost exclusively in soft red winter wheats (17).

Virulence to Lr30, which is associated with virulence to $L r 3 \mathrm{ka}$, increased from $16 \%$ in 1993 (10) to $46 \%$ in 1999 (Table 3). $L r 30$ virulence was common in all areas of the United States in 1999 except area 7. The increase in virulence to $L r 30$ is apparently due to selection for virulence to

Table 3. Percentage of isolates of Puccinia triticina virulent on the single-gene differential lines used in the 1999 survey

\begin{tabular}{|c|c|c|c|c|c|c|c|c|c|c|c|c|c|c|c|c|}
\hline \multirow[b]{2}{*}{ Area $^{a}$} & \multirow[b]{2}{*}{ Source } & \multirow{2}{*}{$\begin{array}{l}\text { No. of } \\
\text { isolates }\end{array}$} & \multicolumn{14}{|c|}{ Isolates virulent on $\operatorname{Lr}$ gene (\%) } \\
\hline & & & 1 & $2 \mathbf{a}$ & $2 \mathrm{c}$ & 3a & $3 \mathbf{k a}$ & 9 & 10 & 11 & 16 & 17 & 18 & 24 & 26 & 30 \\
\hline 1 & Field & 16 & 100 & 31 & 31 & 100 & 56 & 0 & 100 & 69 & 19 & 0 & 25 & 0 & 44 & 56 \\
\hline 1 & Nursery & 296 & 96 & 22 & 26 & 99 & 77 & 15 & 85 & 94 & 0 & 0 & 74 & 8 & 44 & 77 \\
\hline 2 & Field & 4 & 100 & 25 & 25 & 100 & 75 & 25 & 75 & 100 & 0 & 0 & 100 & 0 & 0 & 75 \\
\hline 2 & Nursery & 14 & 100 & 29 & 29 & 100 & 43 & 29 & 71 & 86 & 0 & 14 & 71 & 0 & 21 & 43 \\
\hline 3 & Field & 56 & 100 & 55 & 63 & 100 & 79 & 0 & 100 & 55 & 21 & 13 & 32 & 5 & 54 & 79 \\
\hline 3 & Nursery & 50 & 100 & 36 & 36 & 100 & 64 & 0 & 96 & 70 & 0 & 16 & 34 & 12 & 62 & 64 \\
\hline 4 & Field & 52 & 100 & 37 & 37 & 75 & 13 & 0 & 79 & 27 & 0 & 79 & 2 & 17 & 50 & 19 \\
\hline 4 & Nursery & 147 & 100 & 21 & 21 & 100 & 31 & 1 & 100 & 44 & 2 & 56 & 3 & 27 & 39 & 37 \\
\hline 5 & Field & 3 & 100 & 33 & 33 & 100 & 0 & 0 & 100 & 0 & 0 & 33 & 0 & 67 & 33 & 0 \\
\hline 5 & Nursery & 40 & 100 & 28 & 28 & 100 & 38 & 0 & 100 & 38 & 0 & 50 & 0 & 25 & 40 & 38 \\
\hline 6 & Field & 127 & 100 & 52 & 52 & 100 & 13 & 0 & 100 & 15 & 51 & 33 & 1 & 13 & 54 & 13 \\
\hline 6 & Nursery & 363 & 99 & 58 & 58 & 100 & 33 & 3 & 99 & 30 & 31 & 30 & 2 & 25 & 50 & 33 \\
\hline 7 & Field & 2 & 100 & 0 & 0 & 100 & 0 & 0 & 100 & 100 & 0 & 0 & 0 & 0 & 0 & 0 \\
\hline 7 & Nursery & 10 & 100 & 0 & 0 & 100 & 0 & 0 & 100 & 80 & 0 & 20 & 0 & 0 & 0 & 0 \\
\hline U.S. & Field & 260 & 100 & 47 & 49 & 95 & 31 & 0 & 95 & 31 & 31 & 35 & 11 & 12 & 51 & 32 \\
\hline U.S. & Nursery & 920 & 98 & 37 & 38 & 100 & 48 & 7 & 94 & 57 & 13 & 24 & 28 & 19 & 45 & 49 \\
\hline U.S. & Total & 1,180 & 99 & 39 & 41 & 99 & 44 & 5 & 94 & 51 & 17 & 27 & 24 & 17 & 47 & 46 \\
\hline
\end{tabular}

a Agroecological areas are: 1 (Southeast), 2 (Northeast), 3 (Ohio Valley), 4 (Southern Plains), 5 (Central Plains), 6 (Northern Plains), and 7 (Southwest). See Figure 1. 
$L r 3 k a$, which has been used in Kansas wheat cultivars. Lr30 does not occur in common wheat cultivars in the United States.

Leaf rust resistance genes $L r l, 2 a, 2 c$, $3 a$, and 10 have been used in wheat cultivars in the Great Plains for many years, during which virulence to these genes became common. Most races found in recent years are virulent to $L r l, 3 a$, and 10 . Both the K-- races, which were common before 1985 (12,13), and the S-- races, which were found on wheat in the 1960s (2), are virulent to both $L r 2 a$ and $L r 2 c$. By 1986 , the $\mathrm{M}$-- races replaced $\mathrm{K}$-- races as the most prevalent races in the Great Plains. M-- races are virulent to $L r l$ and $3 a$ but avirulent to $L r 2 a$ and $2 c$. The recent increase of T-- races may indicate another shift in the race pattern of the Great Plains and a return to increased virulence to $L r 2 a$ and $2 c$ as well as $L r l$ and $3 a$.

The genes $\operatorname{Lr} 9,16,24$, and 26 are currently being used in combination with other resistance in many of the U.S. wheat breeding programs (17). During the past 20 years, these genes have lost effectiveness, especially when they were added one gene at a time to new wheat cultivars. $L r 24$ and 26 were highly effective as late as 1985 (13), but now provide little protection. Incidence of virulence to lines with $\operatorname{Lr} 26$ increased from less than $1 \%$ of the total U.S. isolates in 1986 to $47 \%$ in 1999 (Table 3). Virulence to $L r 24$ has ranged from $2 \%$ in 1984 (13) to $17 \%$ in 1999 (Table 3). Cultivars with $\operatorname{Lr} 24$ are widely grown in the southern Great Plains (16).

In the past 10 years, virulence to $\operatorname{Lr} 9$ and 16 has increased when cultivars with these genes have been planted in significant acreage. In the past, virulence to Lr16 has declined when cultivars with Lrl6 lost favor and were removed from production, which has allowed $\operatorname{Lr} 16$ to be recycled in some breeding programs. For example, virulence to $\mathrm{Lr} 16$ declined from $17 \%$ in the U.S. population in 1986 (14), when the cultivar ProBrand 812 was grown on sig- nificant acreage, to less than 1\% in 1997. In 1999, virulence to Lrl6 had again risen to $17 \%$ of the U.S. population, because many of the currently grown spring wheats have Lr16 as part of their resistance (17). Since 1995, cultivars with $\operatorname{Lr} 17$ (e.g., Jagger) have gained popularity, and there has been a corresponding increase in virulence to Lr17. By 1999, more than $27 \%$ of the U.S. leaf rust isolates could attack cultivars with $\operatorname{Lr} 17$.

The history of breeding for leaf rust resistance, especially in winter wheats, has shown that it is a continuous struggle. Whenever new resistant genes have been used alone over significant areas, the corresponding virulence has appeared and increased in the $P$. triticina population within a few years. Therefore, it is important to combine new genes for racespecific resistance with other effective genes for resistance.

\section{ACKNOWLEDGMENTS}

We thank Derrick Damm and Beth Thielen for technical assistance and data analysis.

\section{LITERATURE CITED}

1. Anikster, Y., Bushnell, W. R., Eilam, T., Manisterski, J., and Roelfs, A. P. 1997. Puccinia recondita causing leaf rust on cultivated wheats, wild wheats, and rye. Can. J. Bot. 75:2082-2096.

2. Kolmer, J. A. 1989. Virulence and race dynamics of Puccinia recondita f. sp. tritici in Canada during 1956-1987. Phytopathology 79:349-356.

3. Kolmer, J. A. 1991. Phenotypic diversity in two populations of Puccinia recondita f. sp. tritici in Canada during 1931-1987. Phytopathology 81:311-315.

4. Kolmer, J. A. 1992. Diversity of virulence phenotypes and effect of host sampling between and within populations of Puccinia recondita f. sp. tritici in Canada. Plant Dis. 76:618-621.

5. Kolmer, J. A. 2001. Physiologic specialization of Puccinia triticina in Canada in 1998. Plant Dis. 85:155-158.

6. Leonard, K. J., Roelfs, A. P., and Long, D. L. 1992. Diversity of virulence within and among populations of Puccinia recondita $\mathrm{f}$. sp. tritici in different areas of the United States. Plant Dis. 76:500-504.
7. Long, D. L., and Hughes, M. E. 2000. Small Grain Losses Due to Rust. U.S. Dep. Agric. Agric. Res. Serv., Cereal Dis. Lab. On-line publication CDL-EP\#007. Updated annually.

8. Long, D. L., and Kolmer, J. A. 1989. A North American system of nomenclature for Puccinia recondita f. sp. tritici. Phytopathology 79:525-529.

9. Long, D. L., Leonard, K. J., and Hughes, M. E. 2000. Virulence of Puccinia triticina on wheat in the United States from 1996 to 1998. Plant Dis. 84:1334-1341.

10. Long, D. L., Leonard, K. J., and Roberts, J. J. 1998. Virulence and diversity of wheat leaf rust in the United States in 1993 to 1995. Plant Dis. 82:1391-1400.

11. Long, D. L., Roelfs, A. P., Leonard, K. J., and Roberts, J. J. 1994. Virulence and diversity of Puccinia recondita f. sp. tritici in the United States in 1992. Plant Dis. 78:901-906.

12. Long, D. L., Schafer, J. F., and Roelfs, A. P. 1985. Specific virulence of Puccinia recondita f. sp. tritici in the United States from 1978 through 1983. Plant Dis. 69:343-347.

13. Long, D. L., Schafer, J. F., Roelfs, A. P., and Roberts, J. J. 1986. Virulence and epidemiology of Puccinia recondita f. sp. tritici in the United States in 1985. Plant Dis. 70:1107-1110.

14. Long, D. L., Schafer, J. F., Roelfs, A. P., and Roberts, J. J. 1988. Virulence of Puccinia recondita f. sp. tritici in the United States in 1986. Plant Dis. 72:22-24.

15. Long, D. L., Schafer, J. F., Roelfs, A. P., and Roberts, J. J. 1989. Virulence of Puccinia recondita f. sp. tritici in the United States in 1987. Plant Dis. 73:294-297.

16. Marshall, D. 1992. Virulence of Puccinia recondita in Texas from 1988 to 1990. Plant Dis. 76:296-299.

17. Roelfs, A. P., Hughes, M. E., and Long, D. L. 2000. Rust resistance genes in wheat lines and cultivars. U.S. Dep. Agric. Agric. Res. Serv., Cereal Dis. Lab. On-line publication CDLEP\#006.

18. Rowell, J. B. 1984. Controlled infection by Puccinia graminis f. sp. tritici under artificial conditions. Pages 291-332 in: The Cereal Rusts. Vol. 1, Origins, Specificity, Structure, and Physiology. W. R. Bushnell and A. P. Roelfs, eds. Academic Press, Orlando, FL.

19. Schafer, J. F., and Long, D. L. 1988. Relations of races and virulences of Puccinia recondita f. sp. tritici to wheat cultivars and areas. Plant Dis. 72:25-27.

20. Singh, R. P. 1991. Pathogenicity variations of Puccinia recondita f. sp. tritici and $P$. graminis f. sp. tritici in wheat-growing areas of Mexico during 1988 and 1989. Plant Dis. 75:790-794. 